\title{
Nilai Kemanusiaan dalam Akun Instagram Komunitas Manusaya @ manusaya.project sebagai Dukungan kepada Anak-Anak LPKA Salemba Jakarta (Analisis Isi Kualitatif)
}

\author{
Rizka Dwi Putri Mawardah \\ Fakultas Ilmu Sosial dan Ilmu Politik Universitas Muhammadiyah Prof. DR. Hamka, Jakarta \\ Email korespondensi: rizkadpm@gmail.com
}

\begin{abstract}
A B S T R A K
Kata kunci

Instagram

Manusaya.project

Nilai

Kemanusiaan

Keyword:

Instagram

Manusaya.project

Value

Humanity

Instagram adalah salah satu media baru yang termasuk dalam media sosial. Instagram merupakan media sosial yang efektif dalam penyampaian pesan, karena jutaan orang sudah mempunyai akun Instagram dan aktif menggunakannya. Salah satu akun Instagram yang menyampaikan pesan khusus adalah @manusaya.project. Akun ini mengunggah foto disertai teks foto yang mengandung Nilai Kemanusiaan untuk mengajak masyarakat, agar tidak memberikan stigma kepada anak-anak LPKA Salemba, Jakarta yang sedang berhadapan dengan hukum. Penelitian ini menggunakan paradigma kontruktivisme dan teori isi media untuk memahami bagaimana akun Instagram@manusaya.project menyampaikan nilai kemanusiaan dalam teks foto yang diunggah. Pendekatan penelitian ini adalah kualitatif, jenis penelitian deskriptif dan metode analisis isi kualitatif. Teknik pengumpulan data dilakukan dengan pengamatan terhadap teks, wawancara mendalam, dan studi dokumentasi. Teknik analisis data dilakukan dengan analisis isi kualitatif sebagai metode utama dalam memahami nilai kemanusiaan pada akun instagram @manusaya.project. Hasil penelitian menunjukkan adanya nilai kemanusiaan dalam akun Instagram @manusaya.project yang disampaikan melalui teks foto yang diunggah. Adapun unsur-unsur dalam nilai kemanusiaan, meliputi kebenaran, kedamaian, cinta kasih, kebajikan dan tanpa kekerasan.

A B S T R A C T

Instagram is one of the new media included in social media. Instagram is an effective social media for delivering messages, because millions of people already have Instagram accounts and are actively using it. An Instagram account that delivers messages in particular is the Instagram account belonging to the Manusaya community, the @ manusaya.project account. This account uploads a photo accompanied by photo text containing Human Value to illustrate how the community should not give bad stigma to LPKA Salemba children who are dealing with the law. This study uses the paradigm of constructivism and media content theory to understand how the Instagram account @manusaya.project conveyed the value of humanity in the uploaded photo text. This research approach is qualitative, descriptive research type and uses qualitative content analysis methods. Data collection techniques with qualitative content analysis as the main method of understanding human values on the Instagram account @manusaya.project. The results showed a human value in the Instagram account @manusaya.project submitted in the uploaded photo text. In the photo texts analyzed there are elements of human values, including truth, peace, love, virtue and non-violence
\end{abstract}

\section{PENDAHULUAN}

Komunikasi adalah suatu kebutuhan pokok bagi setiap manusia. Fungsi komunikasi sebagai komunikasi sosial dapat digunakan untuk membangun konsep diri, mengaktualisasikan diri, kelangsungan hidup, memperoleh kebahagiaan dan terhindar dari ketegangan serta tekanan (Mulyana, 2012). Pada era teknologi sekarang ini, media komunikasi berkembang sangat pesat. Dengan adanya Internet, komunikator dengan mudah menyampaikan pesan kepada komunikan secara cepat meskipun berada di jarak yang jauh. Salah satu media komunikasi terkini berbasis Internet adalah media sosial. Media sosial adalah medium di Internet yang memungkinkan pengguna merepresentasikan dirinya maupun berinteraksi dan bekerja sama, berbagi, berkomunikasi dengan pebgguna lain, dan membentuk ikatan sosial secara virtual (Nasrullah, 2015).

Salah satu contoh media sosial yang sedang banyak diminati adalah Instagram. Instagram adalah sebuah aplikasi berbagi foto yang 
memungkinkan pengguna mengambil foto, menerapkan filter digital, dan membagikannya ke berbagai layanan jejaring sosial, termasuk milik Instagram sendiri (Atmoko, 2012). Dilihat dari fungsinya, instagram lebih efektif untuk menyebarkan dan mendapatkan informasi. Informasi yang disebarkan beragam, dari berita fakta hingga berita hoax. Tidak sedikit juga akun Instagram yang mempunyai tujuan-tujuan tertentu misalnya untuk menyebarkan nilai-nilai sosial agar penikmat Instagram menyadari akan nilai tersebut. Dengan kata lain, Instagram sebagai salah satu media untuk merepresentasikan konsep-konsep sosial kepada masyarakat, contohnya akun Instagram @ manusaya.project.

Akun tersebut merupakan milik komunitas peduli kemanusiaan yang bertujuan mewujudkan rasa simpati kepada anak-anak Lembaga Pembinaan Khusus Anak (LPKA). @manusaya.project menggambarkan tentang kehidupan anak-anak yang berhadapan dengan hukum dan saat ini tengah berada di LPKA Salemba Jakarta. Anak-anak tersebut luput dari perhatian bahkan mendapat stigma bahwa mereka adalah para kriminal cilik dan sulit menjadi anak baik lagi. Tanpa diketahui oleh masyarakat, anakanak LPKA sebenarnya menyadari kesalahan mereka namun mereka tidak mengetahui cara untuk keluar dari permasalahannya.

Peneliti tertarik membaca pesan-pesan dalam akun Instagram @manusaya.project yang selalu menyebarkan nilai-nilai kemanusiaan. Pesan kemanusiaan disebarkan menggunakan kata-kata kiasan yang bisa menimbulkan banyak interpretasi bagi para pembaca. Penelitian ini bertujuan untuk menganalisis nilai-nilai kemanusiaan yang ada pada akun tersebut agar masyarakat tahu pesan sebenarnya yang ingin disampaikan oleh akun @manusaya.project dan menyebarkan kepada masyarakat agar masyarakat sadar bahwa anak-anak LPKA Salemba juga membutuhkan dorongan semangat dan perhatian yang besar, dan yang lebih menarik terhadap akun ini adalah statement yang berbunyi \#memanusiakanmanusia.

Teori media baru merupakan sebuah teori yang dikembangkan oleh Pierre Levy, yang mengemukakan bahwa media baru merupakan teori yang membahas mengenai perkembangan media. New Media yang salah satunya yaitu media daring didefinisikan sebagai produk dari komunikasi yang termediasi teknologi yang terdapat bersama dengan komputer digital
(Creeber \& Martin, 2009). New Media merupakan media yang menggunakan internet, media online berbasis teknologi, berkarakter fleksibel, berpotensi interaktif dan dapat berfungsi secara privat maupun secara publik (Mondry, 2008).

Salah satu bagian dari new Media adalah "Network Society". "Network Society" adalah formasi sosial yang berinfrastruktur dari kelompok, organisasi dan komunitas massa yang menegaskan bentuk awal dari organisasi dari segala segi (individu, grup, organisasi, dan kelompok soial). Dengan kata lain, aspek mendasar dari formasi teori ini adalah semua yang memiliki hubungan yang secara luas secara koletivitas (Van Dijk, 2006). Media sosial merupakan sekelompok aplikasi berbasis internet yang dibentuk berdasarkan ideologi dan teknologi web 2.0 yang memungkinkan orang secara mobile dapat menciptakan dan bertukar konten, disebut user-generatedcontent seperti facebook, Instagram, tindr, dan sebagainya (Liliweri, 2015).

Penelitian sejenis pernah dilakukan oleh Monalisa (2019) dengan judul Komunikasi Dakwah melalui Media Sosial Instagram. Hasil penelitiannya menyatakan bahwa penggiat dakwah perlu perencanaan dalam menyampaikan pesan-pesan dakwah di media sosial tersebut, dengan pengetahuan yang diketahui dia tuangkan di Instagram, pesan-pesan dakwah yang dipahami ia publikasikan di media sosial Instagram miliknya dengan maksud dan tujuan yang sama.

Penelitian lain dilakukan Wicaksana, 2018 dengan judul Kontruksi Nilai-nilai Kemanusiaan dalam Foto Erupsi Merapi (Analisis Isi Kualitatif pada Katalog Foto "Erupsi Merapi" karya Boy Thartjanto). Hasil penelitiannya menyatakan bahwa nilai-nilai kemanusiaan yang dikontruksikan dalam delapan foto erupsi Merapi terdapat unsur-unsur nilai kemanusiaan, di antaranya cinta kasih, tanpa kekerasan, kebajikan, kedamaian dan kebenaran.

\section{METODE PENELITIAN}

Pendekatan penelitian ini kualitatif dan jenis penelitiannya deskriptif. Bertujuan membuat deskripsi secara sistematis, faktual, dan akurat tentang fakta-fakta dan sifat-sifat populasi atau objek tertentu (Kriyantono, 2016). Peneliti mencari konsep Nilai Kemanusiaan pada akun Instagram @manusaya.project, kemudian hasilnya dideskripsikan melalui penjabaran- 
penjabaran. Metode penelitian yang digunakan dalam penelitian ini adalah analisis isi (content analysis), yaitu teknik penelitian untuk membuat inferensi-inferensi yang dapat ditiru (replicable), dan dengan memperhatikan konteksnya (Bungin, 2009). Analisis isi kualitatif memfokuskan risetnya pada isi komunikasi yang tersirat (tampak atau manifest). Karena itu tidak dapat digunkan untuk mengetahui isi komunikasi yang tersirat (latent) (Kriyantono, 2016).

Peneliti memilih akun komunitas @manusaya.project untuk diteliti. Dalam akun tersebut terdapat nilai-nilai kemanusiaan yang disebarkan kepada masyarakat agar masyarakat tahu dan mengerti sehingga dapat mengubah pola pikir menjadi manusia baik yang sebenarnya seperti tujuan akun tersebut dibuat. Hal tersebut dapat dikaji menggunakan analisis isi kualitatif. Penelitian ini memfokuskan penelitiannya pada nilai kemanusiaan yang terdapat dalam pesan akuninstagram @manusaya.project.

Pengumpulan data yang digunakan peneliti adalah menggunakan teknik observasi, dokumentasi, dan wawancara mendalam. Analisis data sebagai proses mengorganisasikan dan mengurutkan data ke dalam pola, kategori, dan satuan uraian dasar sehingga dapat ditemukan tema dan dapat dirumuskan hipotesis kerja seperti yang disarankan oleh data. Data pada riset kualitatif yaitu kata-kata atau kalimatkalimat, gambar-gambar dan bukan angka (Kriyantono, 2016).

\section{HASIL DAN PEMBAHASAN}

Akun Instagram@manusaya.project adalah milik sebuah komunitas gerakan kemanusiaan yang bernama Manusaya. Manusaya lahir dari kegelisahan generasi muda yang melihat menurunnya kepercayaan kita kepada kemanusiaan dan terjadinya pergeseran norma sudah tidak lagi dianggap sebagai anomali. Komunitas ini menganggap masyarakat mulai kehilangan harapan bahwa manusia dapat berubah menjadi lebih baik, meskipun memiliki masa lalu yang kelam. Mereka berfokus menyampaikan pesan kemanusiaan kepada masyarakat agar memandang positif anakanak Lembaga Pembinaan Khusus Anak (LPKA) yang hak-haknya dibatasi, karena tindakannya yang keliru.

\section{Analisis Isi Kualitatif Nilai Kemanusiaan dalam Pesan Akun Instagram @manusaya.project}

Setelah melakukan observasi dengan membaca beberapa kali teks foto (caption) yang ada dalam pesan akun Instagram @manusaya.project, dari 90 (sembilan puluh) unggahan pada akun tersebut, ada beberapa unggahan yang dipilih untuk diteliti. Unggahan ini mengandung pesan Nilai Kemanusiaan yang sesuai dengan konsep nilai kemanusiaan yang akan diteliti yakni yang mengandung Kebenaran, Kedamaian, Cinta Kasih, Kebajikan dan Tanpa Kekerasan. Sebagaimana tabel di bawah ini.

\section{Tabel 1. Analisis isi teks foto tentang nilai kemanusiaan dalam pesan akun Instagram@manusaya.project}

\begin{tabular}{|c|c|c|c|}
\hline No & $\begin{array}{l}\text { Teks } \\
\text { Foto }\end{array}$ & $\begin{array}{c}\text { Nilai } \\
\text { Kemanu- } \\
\text { siaan }\end{array}$ & Deskripsi \\
\hline 1. & $\begin{array}{l}\text { Meta- } \\
\text { morfo- } \\
\text { sa } \\
\text { Manu- } \\
\text { sia: } \\
\text { Lahir } \\
\text { Kemba- } \\
\text { li Seja- } \\
\text { tinya } \\
\text { manu- } \\
\text { sia } \\
\text { mem- } \\
\text { punyai } \\
\text { keindah } \\
\text { an, } \\
\text { seperti } \\
\text { kupu- } \\
\text { kupu. } \\
\text { Tapi } \\
\text { bukan- } \\
\text { kah } \\
\text { kupu- } \\
\text { kupu } \\
\text { bera- } \\
\text { wal } \\
\text { dari } \\
\text { seekor }\end{array}$ & $\begin{array}{l}\text { Cinta } \\
\text { Kasih; } \\
\text { “Masyara } \\
\text { kat } \\
\text { mengira } \\
\text { anak- } \\
\text { anak } \\
\text { LPKA } \\
\text { tidak } \\
\text { akan } \\
\text { pernah } \\
\text { berubah. } \\
\text { Yang } \\
\text { sudah } \\
\text { rusak } \\
\text { tidak } \\
\text { akan } \\
\text { pernah } \\
\text { bisa } \\
\text { diperbaiki } \\
\text { Cacian, } \\
\text { makian, } \\
\text { dan } \\
\text { stigma } \\
\text { negatif } \\
\text { dari } \\
\text { masyara- }\end{array}$ & $\begin{array}{l}\text { Dalam teks } \\
\text { foto ini, } \\
\text { Manusaya } \\
\text { menunjukkan } \\
\text { cinta kasihnya } \\
\text { dengan } \\
\text { memberikan } \\
\text { kesempatan } \\
\text { kepada anak- } \\
\text { anak LPKA } \\
\text { untuk } \\
\text { mengubah } \\
\text { hidupnya } \\
\text { menjadi lebih } \\
\text { baik. Dengan } \\
\text { menganalogi- } \\
\text { kannya, seperti } \\
\text { kepompong } \\
\text { yang berubah } \\
\text { menjadi kupu- } \\
\text { kupu yang } \\
\text { cantik. }\end{array}$ \\
\hline
\end{tabular}




\begin{tabular}{|c|c|}
\hline 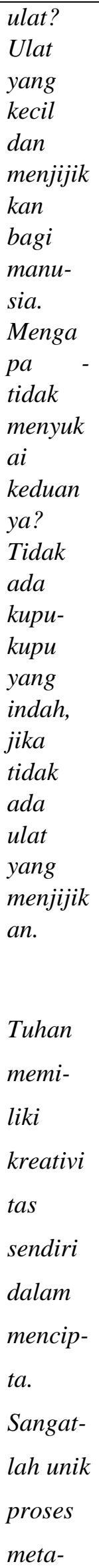 & 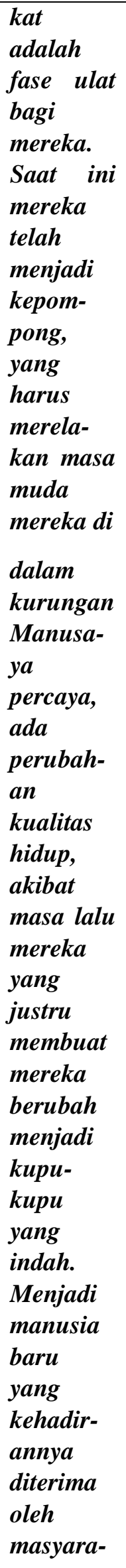 \\
\hline
\end{tabular}

\begin{tabular}{|c|c|}
\hline 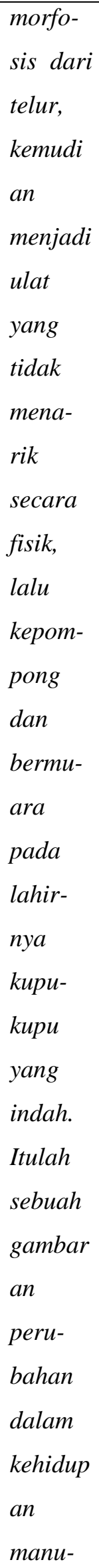 & kat" \\
\hline
\end{tabular}




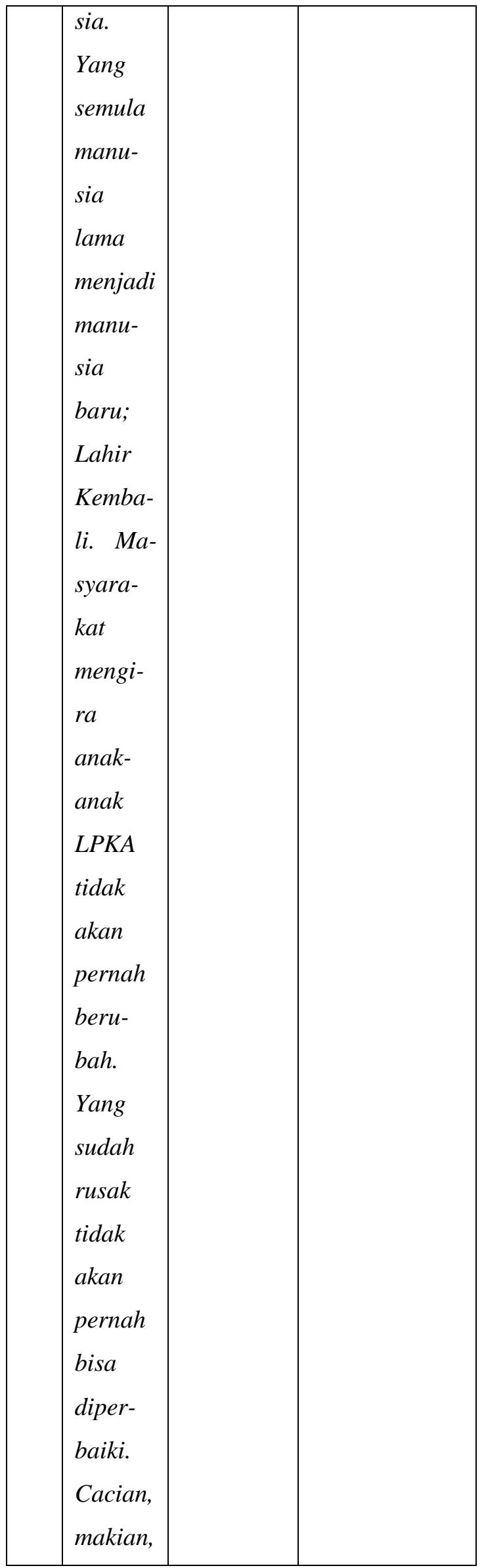

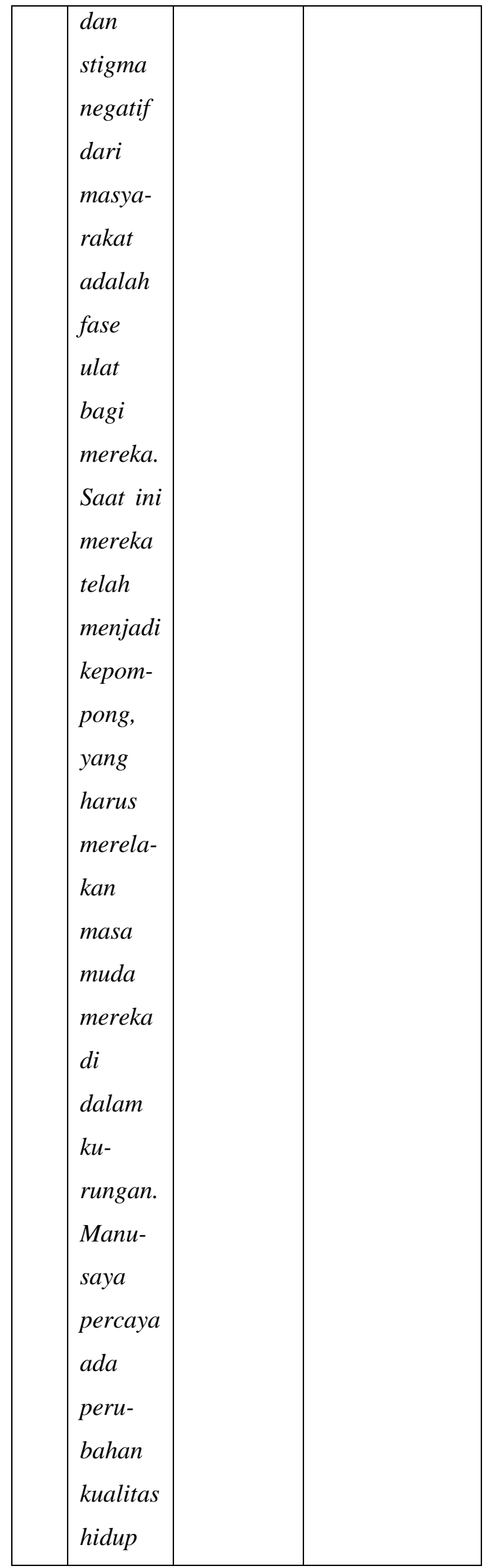




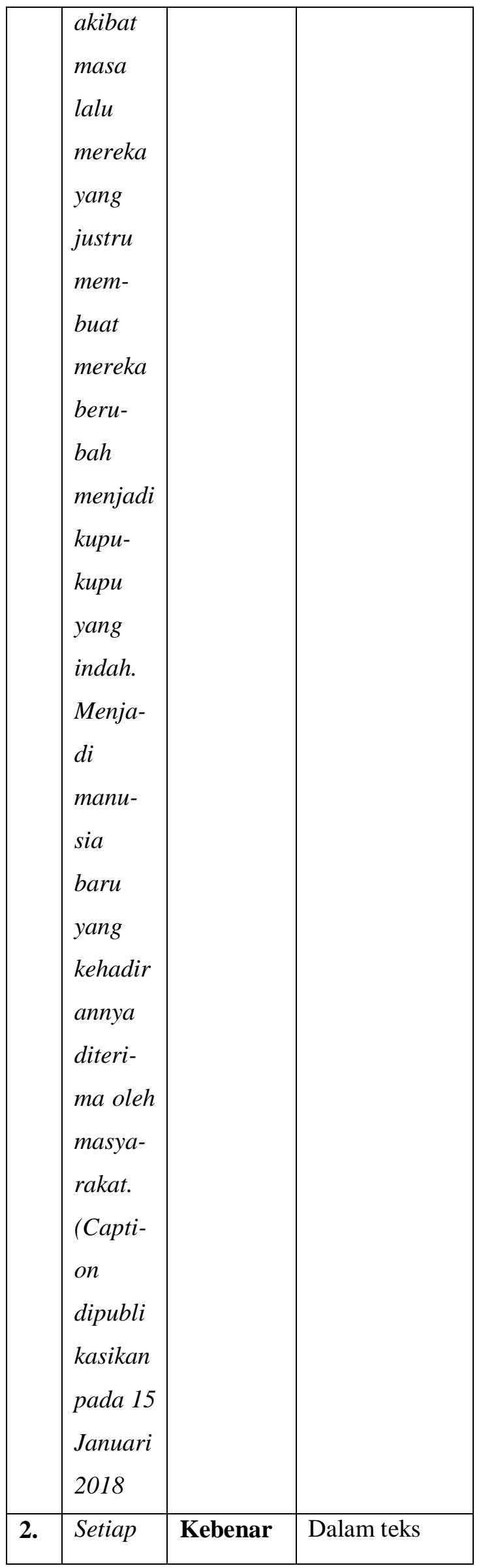

\begin{tabular}{|c|c|c|}
\hline $\begin{array}{l}\text { manu- } \\
\text { sia } \\
\text { harus } \\
\text { memili- } \\
\text { ki } \\
\text { mimpi, } \\
\text { karena } \\
\text { imajina } \\
\text { si dan } \\
\text { hara- } \\
\text { pan } \\
\text { yang } \\
\text { dipupuk } \\
\text { selalu } \\
\text { membe- } \\
\text { rikan } \\
\text { hara- } \\
\text { pan } \\
\text { untuk } \\
\text { menjala } \\
\text { ni } \\
\text { kehidup } \\
\text { anmu } \\
\text { hetiap } \\
\text { hetiap } \\
\text { mana- } \\
\text { sia } \\
\text { punya } \\
\text { kemi } \\
\text { hari. } \\
\text { Jangan } \\
\text { pernah } \\
\text { putus } \\
\text { asa, } \\
\text { karena } \\
\text { mimpi } \\
\text { selalu } \\
\text { punya } \\
\text { jalan- } \\
\text { nya } \\
\text { sendiri. } \\
\text { segal }\end{array}$ & 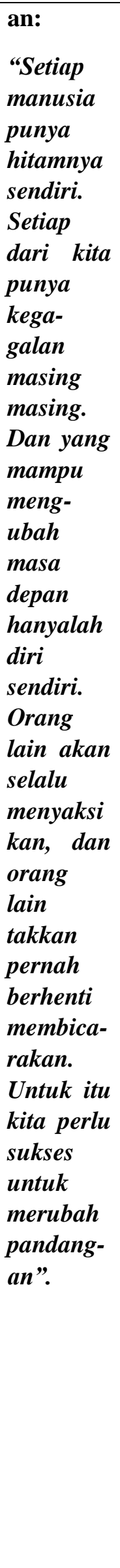 & $\begin{array}{l}\text { foto ini, } \\
\text { Manusaya } \\
\text { menjelaskan } \\
\text { tentang } \\
\text { kebenaran sifat } \\
\text { manusia yang } \\
\text { pasti pernah } \\
\text { melakukan } \\
\text { kesalahan. } \\
\text { Sesuai dengan } \\
\text { definisi nilai } \\
\text { kebenaran } \\
\text { yakni, sesuatu } \\
\text { yang tidak } \\
\text { berubah dan } \\
\text { bersifat kekal, } \\
\text { maka dari itu, } \\
\text { peneliti } \\
\text { mengambil } \\
\text { potongan } \\
\text { hadits yang } \\
\text { relevan dengan } \\
\text { analisis ini. } \\
\text { Hadist yang } \\
\text { berbunyi; } \\
\text { “Setiap anak } \\
\text { Adam pasti } \\
\text { berbuat } \\
\text { salah dan } \\
\text { sebaik-baik } \\
\text { orang yang } \\
\text { berbuat } \\
\text { kesalahan } \\
\text { adalah yang } \\
\text { bertaubat”. } \\
\text { (HR. Tirmidzi) }\end{array}$ \\
\hline
\end{tabular}




\begin{tabular}{|c|c|c|c|}
\hline & $\begin{array}{l}\text { masing. } \\
\text { mereka } \\
\text { yang } \\
\text { mampu } \\
\text { mengu- } \\
\text { bah } \\
\text { masa } \\
\text { depan } \\
\text { hanya- } \\
\text { lah diri } \\
\text { sendiri. } \\
\text { Orang } \\
\text { lain } \\
\text { akan } \\
\text { selalu } \\
\text { menyak } \\
\text { sikan, } \\
\text { dan } \\
\text { orang } \\
\text { lain tak } \\
\text { kan } \\
\text { pernah } \\
\text { berhen- } \\
\text { ti } \\
\text { membi- } \\
\text { cara- } \\
\text { kan. } \\
\text { Untuk } \\
\text { itu kita } \\
\text { perlu } \\
\text { sukses } \\
\text { untuk } \\
\text { meng- } \\
\text { ubah } \\
\text { pan- } \\
\text { dangan. } \\
\text { (Capti- } \\
\text { on } \\
\text { dipubli } \\
\text { kasikan } \\
\text { pada 19 } \\
\text { Januari }\end{array}$ & & \\
\hline 3. & $\begin{array}{l}\text { Mereka } \\
\text { berbe- } \\
\text { nah, } \\
\text { me- } \\
\text { mungut } \\
\text { hujatan }\end{array}$ & $\begin{array}{l}\text { Kedamai } \\
\text { an } \\
\text { “Kini } \\
\text { kurungan } \\
\text { tidak lagi }\end{array}$ & $\begin{array}{l}\text { Dalam teks } \\
\text { foto ini, } \\
\text { Manusaya } \\
\text { menjelaskan } \\
\text { bagaimana } \\
\text { Anak-anak }\end{array}$ \\
\hline
\end{tabular}

\begin{tabular}{|c|c|c|}
\hline 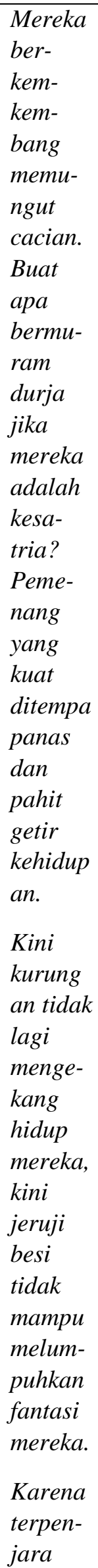 & 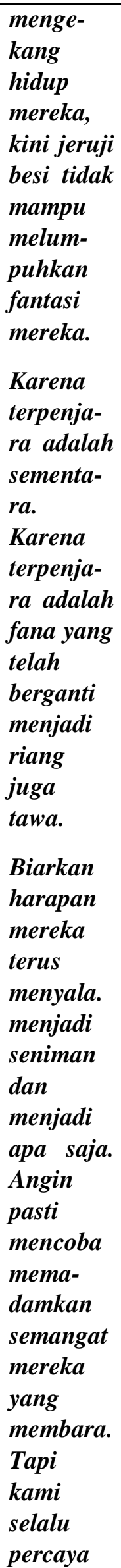 & $\begin{array}{l}\text { LPKA } \\
\text { memberikan } \\
\text { kedamaian } \\
\text { pada diri } \\
\text { mereka. } \\
\text { Bagaimana } \\
\text { mereka tidak } \\
\text { harus luput } \\
\text { dalam } \\
\text { penyesalan } \\
\text { atas kesalahan } \\
\text { yang pernah } \\
\text { mereka } \\
\text { lakukan. }\end{array}$ \\
\hline
\end{tabular}




\begin{tabular}{|c|c|}
\hline 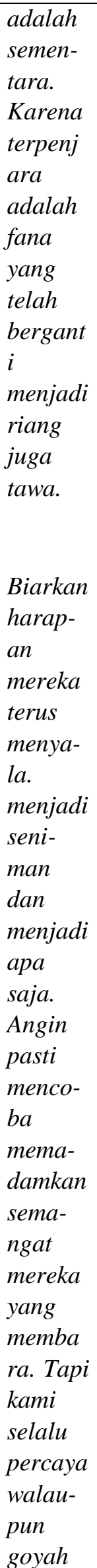 & $\begin{array}{l}\text { walaupun } \\
\text { goyah } \\
\text { mereka } \\
\text { takkan } \\
\text { pernah } \\
\text { patah, } \\
\text { melain- } \\
\text { kan } \\
\text { berbuah } \\
\text { menjadi } \\
\text { manusia } \\
\text { seutuh- } \\
\text { nya” }\end{array}$ \\
\hline
\end{tabular}

\begin{tabular}{|c|c|c|c|}
\hline & $\begin{array}{l}\text { mereka } \\
\text { takkan } \\
\text { pernah } \\
\text { patah, } \\
\text { melain- } \\
\text { kan } \\
\text { berbu- } \\
\text { ah } \\
\text { menjadi } \\
\text { manu- } \\
\text { sia } \\
\text { seutuh- } \\
\text { nya. } \\
\text { (Capti- } \\
\text { on } \\
\text { dipubli } \\
\text { kasikan } \\
\text { pada } 19 \\
\text { Januari } \\
\text { 2018) }\end{array}$ & & \\
\hline 4. & $\begin{array}{l}\text { Banyak } \\
\text { yang } \\
\text { pernah } \\
\text { bilang } \\
\text { mereka } \\
\text { ini } \\
\text { tidak } \\
\text { berda- } \\
\text { ya. } \\
\text { Tetapi } \\
\text { kemau- } \\
\text { an, } \\
\text { keingin } \\
\text { an dan } \\
\text { gairah } \\
\text { belajar } \\
\text { mereka } \\
\text { bisa } \\
\text { merun- } \\
\text { tuhkan } \\
\text { stigma } \\
\text { apa pun } \\
\text { yang } \\
\text { dilem- } \\
\text { parkan. } \\
\text { Tak } \\
\text { jarang } \\
\text { juga } \\
\text { yang }\end{array}$ & $\begin{array}{l}\text { Perilaku } \\
\text { yang } \\
\text { Benar } \\
\text { atau } \\
\text { Kebajika } \\
\mathrm{n} ; \\
\text { "Sebagia } \\
n \\
\text { masyarak } \\
\text { at } \\
\text { menyebut } \\
\text { mereka } \\
\text { malang. } \\
\text { Tetapi } \\
\text { dengan } \\
\text { uluran } \\
\text { tangan, } \\
\text { senyuma } \\
\text { n, gelak } \\
\text { tawa, dan } \\
\text { kehadira } \\
n \quad \text { kami, } \\
\text { kami } \\
\text { coba } \\
\text { topang } \\
\text { mereka. } \\
\text { Lalu kini } \\
\text { kami }\end{array}$ & $\begin{array}{l}\text { Dalam teks } \\
\text { foto ini, } \\
\text { Manusaya } \\
\text { melakukan } \\
\text { kebajikan } \\
\text { dengan } \\
\text { memberikan } \\
\text { uluran tangan } \\
\text { senyuman dan } \\
\text { gelak tawa. } \\
\text { Salah satunya } \\
\text { dengan cara } \\
\text { merekam } \\
\text { mimpi-mimpi } \\
\text { mereka dalam } \\
\text { ingatan dan } \\
\text { melukis angan } \\
\text { di atas kanvas. } \\
\text { Kemudian } \\
\text { mereka } \\
\text { menciptakan } \\
\text { karya untuk } \\
\text { ditunjukkan } \\
\text { kepada } \\
\text { masyarakat } \\
\text { bahwa mereka } \\
\text { mempunyai } \\
\text { kesempatan } \\
\text { menjadi }\end{array}$ \\
\hline
\end{tabular}




\begin{tabular}{|c|c|c|}
\hline $\begin{array}{l}\text { mendik- } \\
\text { te } \\
\text { bahwa } \\
\text { mereka } \\
\text { adalah } \\
\text { kegagal } \\
\text { an. } \\
\text { Tetapi } \\
\text { dukung } \\
\text { an, } \\
\text { keperca } \\
\text { yaan, } \\
\text { hara- } \\
\text { pan dan } \\
\text { aksi } \\
\text { mampu } \\
\text { mema- } \\
\text { tahkan- } \\
\text { nya. } \\
\text { Sebagi- } \\
\text { an } \\
\text { masya- } \\
\text { kami } \\
\text { rakat } \\
\text { menye- } \\
\text { but } \\
\text { mamini } \\
\text { mereka } \\
\text { malang. } \\
\text { Tetapi } \\
\text { dengan } \\
\text { uluran } \\
\text { tangan, } \\
\text { senyum } \\
\text { an, } \\
\text { gelak } \\
\text { tawa, } \\
\text { dan } \\
\text { kehadir } \\
\text { an } \\
\text { kami, } \\
\text { mana } \\
\text { mani }\end{array}$ & $\begin{array}{l}\text { bersama } \\
\text { anak- } \\
\text { anak } \\
\text { LPKA } \\
\text { Salemba } \\
\text { merekam } \\
\text { mimpi- } \\
\text { mimpi } \\
\text { dalam } \\
\text { ingatan, } \\
\text { melukis } \\
\text { angan di } \\
\text { atas } \\
\text { kanvas. } \\
\text { Disaksi- } \\
\text { kan } \\
\text { manusia- } \\
\text { manusia. } \\
\text { Kemudi- } \\
\text { an } \\
\text { berkarya } \\
\text { dan } \\
\text { membung } \\
\text { kam } \\
\text { setiap } \\
\text { insan } \\
\text { yang } \\
\text { pernah } \\
\text { memung- } \\
\text { gungi } \\
\text { mereka”. }\end{array}$ & $\begin{array}{l}\text { manusia baik } \\
\text { dan berguna. }\end{array}$ \\
\hline
\end{tabular}

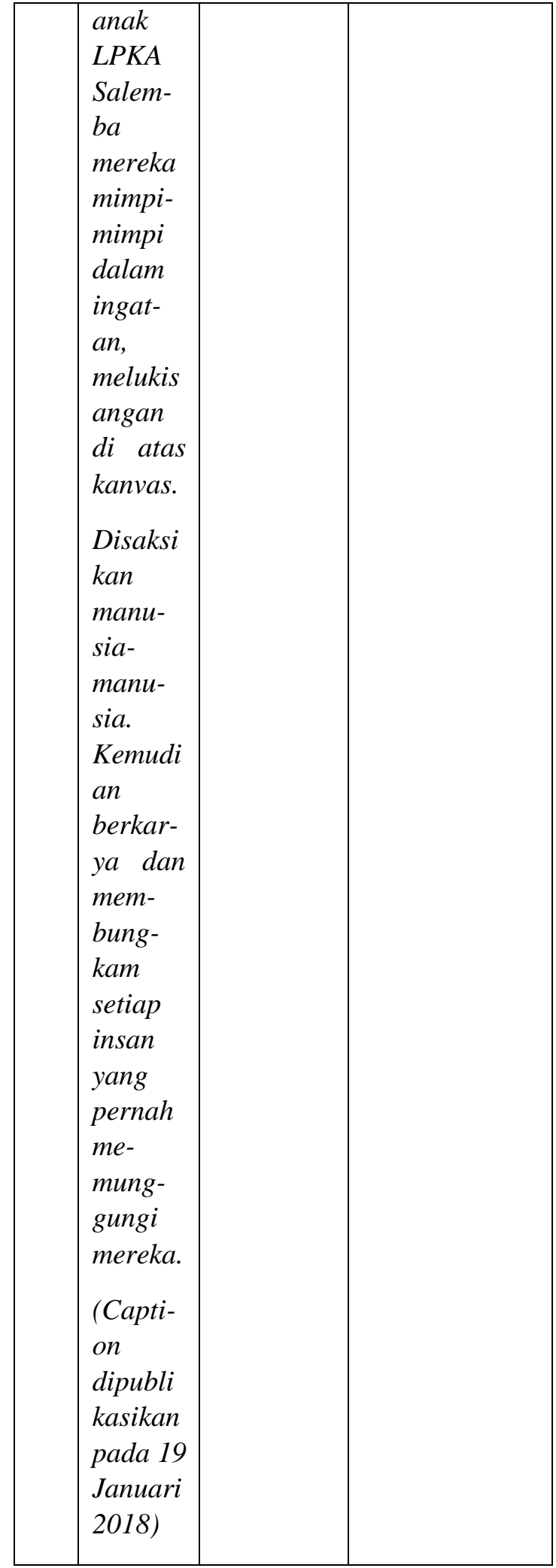

Nilai Kemanusiaan dalam Akun Instagram Komunitas Manusaya @manusaya.project sebagai Respon Positif kepada Anak-anak LPKA Jakarta Salemba 
Hasil analisis peneliti menunjukkan, beberapa unggahan yang terdapat di dalam akun Instagram @ manusaya.project menggambarkan sebuah Nilai Kemanusiaan yang disampaikan melalui teks foto dari sebuah foto yang diunggah, dalam teks foto unggahan tersebut mengandung Nilai Kemanusiaan dalam hal cinta kasih, kedamaian, kebaikan, perilaku yang benar atau kebajikan dan tanpa kekerasan. Hal tersebut diungkapkan oleh Gabriella Tania, ketua komunitas Manusaya yang juga menjadi penanggung jawab isi unggahan akun @ manusaya.project.

\section{Kebenaran sebagai Nilai Kemanusiaan}

Nilai kebenaran adalah segala sesuatu hal yang sifatnya benar di kehidupan manusia. Sifatsifat manusia yang sering muncul dalam kehidupan antarsesama. Tidak dipungkiri, manusia mempunyai sifat yang selalu merasa benar sehingga mudah sekali menilai orang lain buruk. Padahal semua manusia di mata Tuhan sama saja tetapi bagaimana manusia sendiri menyadari kesalahannya dan mau mengubah hidupnya menjadi lebih baik. Nilai kebenaran terlihat pada teks foto 2 .

Pada teks foto 2, teks foto tersebut menjelaskan setiap manusia pasti pernah melakukan kesalahan. Hanya diri sendiri yang bisa merubah keadaan, karena orang lain hanya bisa mengomentari kesalahan seseorang. Ketika kita bisa bangkit dan sukses, orang lain pun akan merubah komentar negatif mereka menjadi positif.

\section{Kedamaian sebagai Nilai Kemanusiaan}

Kedamaian adalah bagaimana manusia melakukan perenungan terhadap diri sendiri atau intropeksi diri dari semua kesalahan yang sudah diperbuat. Pengalaman buruk menjadi pembelajaran untuk mengubah kehidupan yang baru menjadi lebih baik. Nilai kedamaian terlihat pada narasi 3. Pada teks foto 3, teks foto tersebut menjelaskan bagaimana anak-anak LPKA melakukan intropeksi diri dari pengalaman buruk yang pernah mereka jalani untuk memulai dan menata kehidupan baru yang baik. Walaupun banyak stigma buruk yang menghantui mereka dengan mereka belajar untuk memperbaiki kesalahan dan membuktikan kepada masyarakat, mereka akan berhasil menghapus stigma buruk tersebut. Kedamaian yang dimaksud dalam analisis ini adalah bagaimana anak-anak LPKA memberikan kedamaian pada diri sendiri.

\section{Cinta Kasih sebagai Nilai Kemanusiaan}

Cinta kasih adalah sebuah bentuk perwujudan antarsesama manusia atau makhluk hidup lainnya. Antarsesama manusia harus saling menunjukkan kepedulian dan perhatiaannya terlepas mereka pernah melakukan kesalahan. Dengan melakukan hal tersebut, setiap manusia akan merasa dihargai sehingga tercipta kehidupan bermasyarakat yang harmonis. Nilai cinta kasih terlihat pada narasi 1 . Pada teks foto 1 , teks foto tersebut menunjukan bagaimana Manusaya menunjukan kepedulian dan perhatiannya dengan memberikan kesempatan anak-anak LPKA lahir kembali menjadi manusia seutuhnya dengan menganalogikan seperti kepompong yang dilihat buruk akan berubah menjadi kupu-kupu yang indah.

Terlepas dengan kesalahan yang pernah mereka lakukan, dengan memberikan perhatian dan cinta kasih dari masyarakat akan membuat anak-anak LPKA merasa adanya dukungan untuk mereka melakukan perubahan yang baik di lingkungannya. Menjadikan kesalahan sebagai pengalaman yang akan terus diingat dan dipelajari untuk mengubah hidup lebih baik. Dukungan terhadap anak-anak LPKA akan membentuk konsep diri yang baik untuk mereka. Konsep diri menjadi penting ketika mereka kembali menjalani kehidupan ketika sudah keluar dari LPKA.

\section{Perilaku yang Benar atau Kebajikan sebagai Nilai Kemanusiaan}

Hal kebajikan merupakan perbuatan baik dan benar yang dilakukan oleh manusia untuk memberikan praktek kepedulian dan berbuat baik untuk mendukung perubahan yang baik kepada orang lain. Kebajikan kerap kali disandingkan dengan persatuan yang terkonsep melakukan kebajikan dalam bentuk kepedulian. Nilai Kebajikan terlihat pada narasi 4. Pada teks foto 4 , teks foto tersebut menunjukkan bagaimana Manusaya melakukan perbuatan kebajikan dengan menunjukkan kepada masyarakat untuk memberikan dukungan, kepercayaan, harapan dan aksi dengan memeberikan uluran tangan senyuman dan gelak tawa. Salah satunya dengan cara merekam mimpi-mimpi mereka dalam ingatan dan melukis angan di atas kanvas. Kemudian mereka menciptakan karya untuk ditunjukkan kepada masyarakat bahwa mereka mempunyai kesempatan menjadi manusia baik dan berguna. 
Dalam hal ini, anak-anak LPKA sebenarnya membutuhkan dukungan sosial dari masyarakat. Menurut Sarafino dalam Oktavia, L (2002) dukungan sosial terdiri dari empat jenis yaitu :

a. Dukungan emosional. Dukungan ini melibatkan ekspresi rasa empati dan perhatian terhadap individu, sehingga individu tersebut merasa nyaman, dicintai dan diperhatikan. Dukungan ini meliputi perilaku seperti memberikan perhatian dan afeksi seta bersedia mendengarkan keluh kesah orang lain.

b. Dukungan penghargaan. Dukungan ini melibatkan ekspresi yang berupa pernyataan setuju dan penilaian positif terhadap ide-ide, perasaan dan performa orang lain.

c. Dukungan instrumental. Bentuk dukungan ini melibatkan bantuan langsung, misalnya yang berupa bantuan finansial atau bantuan dalam mengerjakan tugas tugas tertentu.

d. Dukungan informasi. Dukungan yang bersifat informasi ini dapat berupa saran, pengarahan dan umpan balik tentang bagaimana cara memecahkan persoalan.

Sebagaimana dikemukakan McQuail dalam teori isi media, bahwa isi media merupakan pesan atau informasi yang disampaikan kepada khalayak. Terkait dengan hal di atas, setiap media sosial mempunyai pesan yang ingin disampaikan, begitu pula salah satu media sosial yakni Instagram @manusaya.project. Akun tersebut menyampaikan pesan yang terkait dengan Nilai Kemanusiaan yang sudah luntur di tengah masyarakat dan memfokuskan penyampaian pesan nilai kemanusian sebagai dukungan kepada anak-anak LPKA untuk mengubah stigma buruk masyarakat yang melekat pada mereka.

Menurut Goffman, stigma merupakan tandatanda yang dibuat pada tubuh seseorang untuk diperlihatkan dan menginformasikan kepada masyarakat bahwa orang-orang yang mempunyai tanda-tanda tersebut merupakan seorang buruh, kriminal, atau seorang penghianat. Stigma buruk yang timbul dari tanda-tanda yang ada pada diri anak-anak LPKA, yakni anak-anak tersebut pernah berhubungan dengan hukum karena kesalahan yang pernah mereka lakukan seperti mencuri, tawuran, narkoba dsb. Tanda-tanda tersebut dinilai masyarakat akan selalu melekat pada mereka walaupun mereka ingin mengubah hidupnya lebih baik. Masyarakat juga menilai mereka akan selalu mengulangi kesalahan yang sama. Anak-anak LPKA dianggap manusia kriminal yang tidak akan bisa mengubah hidupnya lebih baik setelah mereka pernah melakukan kesalahan dan mendekam di Lembaga Pembinaan Khusus Anak (LPKA).

Mengenai stigma buruk kepada anak-anak LPKA Gabriella Tania, Ketua Komunitas Manusaya menjelaskan sebagai berikut,

"Orang-orang seringkali mengabaikan mereka. Padahal mereka ini juga manusia yang masih punya kehidupan. Mereka masih muda banget dan punya masa depan, tapi mereka sudah dirusak oleh stigma di lingkungan. Mereka gak bisa kerja garagara stigma. Mereka gak bisa sekolah lagi gara-gara stigma. Mereka gak bisa balik ke lingkungannya, karena lingkungannya sudah menstigma mereka."

Anak-anak LPKA seharusnya diberikan kesempatan hidup lebih baik, karena mereka masih muda dan masih bisa menggapai masa depan dengan cara kreatif mereka. Mereka juga sebagai generasi penerus bangsa yang harus diberikan perhatian dan dukungan. Ketika adanya stigma buruk kepada anak-anak LPKA, hal tersebut dapat menghalangi mereka untuk mencoba lebih baik di lingkungannya setelah mereka keluar dari LPKA.

Dalam hal ini, erat kaitannya dengan konsep diri yang akan dibangun oleh mereka. Ketika masyarakat memberikan hal-hal positif kepada mereka seperti memberikan semangat, perhatian, dukungan dan kesempatan untuk mereka menjalani hidupnya sama seperti anak-anak yang lain, maka mereka akan merasa adanya manusiamanusia baik yang bisa menerima mereka terlepas dari kesalahan yang pernah dilakukan. Sehingga mereka dapat menjalani hidupnya lebih baik tanpa adanya ketakutan penilaian dari masyarakat.

Sebaliknya, ketika masyarakat memberikan stigma buruk dengan menjauhi dan mendisrikminasi mereka serta memberikan penilaian-penilaian buruk, hal tersebut akan menghalagi mereka dalam perubahan hidupnya. Mereka akan merasa bahwa sudah tidak ada kesempatan lagi untuk mereka mengubah hidupnya, sehingga mereka akan mengulangi kesalahannya lagi karena mereka menganggap sudah tidak ada yang peduli dengannya. 
Maka dari itu, akun @manusaya.project dibuat oleh komunitas Manusaya untuk menunjukkan kepada masyarakat sisi lain anakanak LPKA dengan cara menyampaikan pesan nilai kemanusiaan melalui teks foto yang diunggah. Akun ini sebagai jembatan bagi anakanak LPKA untuk mengubah stigma buruk yang melekat pada mereka di lingkungan masyarakat agar masyarakat sadar bahwa anak-anak tersebut layak menjadi manusia baik lagi seperti manusia lainnya.

Dalam akun ini, adanya penyampaian tentang anak-anak yang bercerita bahwa sebenarnya mereka sudah sadar atas kesalahannya dan mau memperbaikinya namun mereka terhalang stigma-stigma yang ada lingkungan mereka nantinya. @manusaya.project juga menyampaikan pesan-pesan nilai kemanusiaan melalui beberapa teks foto yang mengandung kebenaran, kedamaian, cinta kasih, kebajikan dan tanpa kekerasan.

Penyampaian pesan nilai kemanusiaan dalam akun@manusaya.project untuk menghilangkan stigma buruk kepada anak-anak LPKA juga disampaikan oleh Gabriella Tania Hal selaku Ketua Komunitas Manusaya sekaligus salah satu penanggung jawab konten akun tersebut sebagai berikut:

"Kita mencoba membuat konten yang bikin orang bangga kalau dia aware sama konten ini. Makanya awal-awal kalau liat kontennya lebih general, tapi disisi lain itu masih membawa perhatian kepada anak-anak".

"Jadi dulu kita coba cari tentang nilai kemanusiaan tapi lagi-lagi ga ada yang spsesifik, yaudah kita coba aplikasiin yang kita percaya. Kemanusiaan prinsipnya adalah gimana lu bisa liat manusia lain sebagai manusia dan lo sadar kalau kita tuh sama. Dan kita mau menambahkan unsur soal kasih karna kita percaya hanya kasih yang bisa membuat seseorang bepikir. Kalau kamu udah sayang, kamu ga akan melakukan kekerasan, disekitar kamu akan merasa nyaman dengan kedamaian".

Setelah dibuatnya akun @manusaya.project dengan tujuannya yakni menghilangkan stigma buruk masyarakat kepada anak-anak LPKA, maka timbulah dampak yang diharapkan komunitas tersebut. Dampaknya adalah masyarakat bisa mengetahui anak-anak LPKA yang sebenarnya membutuhkan perhatian dan dukungan dengan merespon akun tersebut dengan cara mengirimkan pesan untuk mengetahui kabar dan perkembangan anak-anak di LPKA. Pengikut akun Instagram tersebut juga rutin meminta cerita lengkap ketika Manusaya telah melakukan kunjungan yang akan dikirim melalui email. Hal tersebut dijelaskan oleh Gabriella Tania sebagai Ketua Komunitas Manusaya sekaligus penanggung jawab konten yang memantau akun Instagram@manusaya.project:

"Kita sering terima direct message orang untuk nanyain kabar anak-anak. Oily, ketika kami bikin program kaya mentoring, mereka mau datang dan menjadi mentor. Dan itu yang kami targetkan. Kami mencoba membuat konten yang bikin orang bangga kalau dia aware sama konten ini. Makanya awal-awal kalau lihat kontennya lebih general, tapi di sisi lain itu masih membawa perhatian kepada anak-anak”.

Dampak tersebut juga disampaikan langsung oleh salah satu pembaca akun Instagram @manusaya.project yakni Hayun Rizkia sebagai berikut:

"Awalnya saya tidak pernah berpikir tentang bagaimana keadaan anak-anak LPKA. Sampai Manusaya hadir untuk memberikan sisi lain dari anak-anak LPKA ini. Saya sepakat bahwa setiap manusia pasti pernah melakukan kesalahan baik disengaja maupun tidak. Buat saya, akun ini memberikan pesan lebih dari sekedar cerita anak-anak LPKA. Manusaya memberikan arti pentingnya belajar dari kesalahan, pentingnya memberi kesempatan untuk orang yang pernah bersalah. Manusaya dalam akun ini memperlihatkan kepada kita bahwa bagian penting dari hidup berdampingan adalah memanusiakan manusia. Saya melihat anak-anak LPKA dengan penuh keyakinan bahwa mereka masih memiliki masa depan yang cerah, seperti impian mereka, tanpa melihat masa lalunya."

Berdasarkan pemaparan di atas, akun @manusaya.project dapat membuat masyarakat mengerti dan sadar akan nilai kemanusiaan yang sudah luntur dalam dirinya sehingga stigma buruk kepada anak-anak LPKA perlahan mulai hilang. Maka dari itu, tampak bahwa akun Instagram @manusaya.project memiliki isi pesan yang disampaikan yakni, pesan yang mengandung Nilai Kemanusiaan yang 
seharusnya dilakukan di masyarakat dalam kehidupan antarsesama. Dalam hal ini pula, media sosial Instagram bisa menjadi media populer yang efektif untuk menyampaikan pesan kepada khalayak atau masyarakat yang bertujuan agar masyarakat tersadar dari nilai-nilai yang mulai luntur di tengah lingkungannya dan salah satunya yaitu nilai kemanusiaan.

Dengan cara memanusiakan antarsesama manusia terlepas dari kesalahan yang pernah dilakukan anak-anak LPKA, karena isi pesan akun tersebut juga menjelaskan bagaimana anakanak LPKA menceritakan bahwa sebenarnya ingin merubah dirinya lebih baik namun terhalang oleh stigma buruk masyarakat yang membuat mereka putus asa. Akun @ manusaya.project mampu menjadi jembatan antara anak-anak LPKA dan masyarakat untuk menghilangkan stigma buruk.

\section{Kesimpulan}

Berdasarkan hasil penelitian dan pembahasan pada bab sebelumnya, maka dapat ditarik kesimpulan sebagai berikut:

1. Berdasarkan hasil analisis sembilan teks foto pada akun Instagram @manusaya.project, yang merupakan gambaran dari kehidupan anak-anak LPKA yang mengandung nilai kemanusiaan yang terwujud dalam kebenaran, kedamaian, cinta kasih, kebajikan dan tanpa kekerasan. Akun tersebut menyampaikan pesan kemanusiaan yang dituangkan melalui narasi sebuah unggahan dengan menyampaikan hal-hal yang seharusnya dilakukan masyarakat seperti, memberikan perhatian dan semangat, melakukaan kegiatan-kegiatan yang membuat anak-anak LPKA tidak tenggelam dalam penyesalan sehingga mereka merasa adanya kepedulian dari masyarakat dan harapan yang membuat mereka bisa mengubah kehidupan menjadi lebih baik.
2. Hasil analisis dan wawancara mendalam serta data pendukung lainnya memberikan gambaran terdapatnya Nilai Kemanusiaan dalam teks narasi tersebut. Pesan yang disampaikan Komunitas Manusaya pada teks foto merupakan pesan kepada masyarakat bahwa nilai kemanusiaan yang mulai luntur harus dibangun kembali, khususnya ditujukan pada anak-anak LPKA. Masyarakat diharapkan menghapus stigma buruk terhadap anak-anak LPKA

\section{References}

Atmoko, Bambang Dwi. (2012). Handbook Instagram. Jakarta: Media Kita

Bungin, Burhan. 2009.

Kriyantono. (2016). Teknik Praktis Riset Komunikasi. Jakarta: Kencana Prenada Media Group

Liliweri. (2015). Komunikasi Antar Personal. Jakarta: Kencana

Mondry. (2008). Teori dan Praktik Jurnalistik. Bogor: Ghalia Indonesia.

Mulyana, Deddy. (2012). Ilmu Komunikasi Suatu Pengantar. Bandung: PT Remaja Rosdakarya.

Nasrullah. (2015). Media Sosial. Bandung: Simbiosa Rekatama Media.

Oktavia, L dan Basri, A.S. (2002). Hubungan Antara Dukungan Sosial Yang Diterima Secara Nyata dengan Ada atau Tidaknya Gangguan Depresi Pasca Persalinan Pada Ibu Dewasa Muda. Jurnal Psikologi Sosial. ISSN 08533997. Volume 8. Nomor 1. Halaman 15-18. Diakses pada Jum'at 2 Agustus 2019 pukul 21.46 WIB

Rianse, Usman\&Abdi. (2012). Metodologi Penelitian Sosial dan Ekonomi (Teori dan Aplikasi). Bandung: Alfabeta

http://ppg.spada.ristekdikti.go.id/ (diakses Jum'at 12 Maret pukul 01.35 WIB)

https://databoks.katadata.co.id/datapublish/2018/02/09

/berapa-pengguna-instagram-dari-indonesia (diakses Senin 24 Juni 2019 pukul 22.35 WIB)

https://www.gurupendidikan.co.id/bhineka-tunggalika/ (diakses Jum'at 2 Agustus 2019 pukul 21.00 WIB) 